\title{
Neurofibromatosis Type 1-related Multiple Plexiform Neurofibromas: A Case Report
}

\author{
Nörofibromatozis Tip 1 İlişkili Multipl Pleksiform Nörofibromlar: Bir Olgu Sunumu
}

\author{
(1) Tamer Bayram¹, (ㅇ Derya Bayram², (1) Hülya Tireli3 \\ 1Beykoz State Hospital, Clinic of Neurology, Istanbul, Turkey \\ 2University of Health Sciences Turkey, Sancaktepe Şehit Prof. Dr. IIhan Varank Training and Research Hospital, Clinic of Neurology, Istanbul, Turkey \\ 3istanbul Haydarpaşa Numune Training and Research Hospital, Clinic of Neurology, Istanbul, Turkey
}

\begin{abstract}
Neurofibromatosis type 1 (NF1) and type 2 (NF2) are autosomal dominant diseases. Patients with NF1 or NF2 have the potential to develop benign and malignant tumors. We present a 17-year-old patient with undiagnosed NF1-related multiple plexiform neurofibromas (PNs). The patient was admitted to our department for his left limb paresthesia. He had café-au-lait spots spread over his body and his cervical, thoracic, and lumbosacral magnetic resonance imaging (MRI) of the spine showed multiple PNs. Among his family members, only his father had café-au-lait spots. He refused to have genetic analysis and biopsy of the lesions. Even though clinical symptoms of neurofibromas vary according to the localization of lesions, it is known that PNs could be asymptomatic throughout life. Surgical treatment for PNs is essential. Phase 2 clinical trials have been performed for the medical treatment of PNs and further research on this subject is ongoing. Extensive growth of the tumors and invasion of surrounding tissues made resection of PNs difficult in the patient. Therefore, he had annual MRI follow-ups to assess the growth rate of the neurofibromas and transformation to malignant peripheral nerve-sheath tumors. This case was demonstrative to show multiple PNs. The presence of as much multiple PNs as in our patient is rare.
\end{abstract}

Keywords: Neurofibromatosis type 1, plexiform neurofibroma, spinal tumor

$\ddot{O} \mathbf{z}$

Nörofibromatozis tip 1 (NF1) ve tip 2 (NF2) otozomal dominant hastalıklardır. NF1 veya NF2 olan hastalar benign ve malign tümörler geliştirme potansiyeline sahiptir. NF1 tanısı olmayan çok sayıda pleksiform nörofibromu (PN) olan 17 yaşında bir hastayı sunduk. Hasta sol bacak parestezisi nedeniyle bölümümüze başvurdu. Vücudunda yaygın café-au-lait lekeleri olan hastanın servikal, torasik ve lumbosakral spinal manyetik rezonans görüntülemesinde (MRG) birden fazla PN saptandı. Aile üyeleri arasında sadece babasının café-au-lait lekeleri vardı. Hastamız genetik analiz ve lezyon biyopsisi yaptırmayı reddetti. Nörofibromların klinik semptomları lezyonların lokalizasyonuna göre değişmekle birlikte, PN’lerin yaşam boyunca asemptomatik olabileceği bilinmektedir. Cerrahi tedavi PN'ler için esastır. PN'lerin medikal tedavisi için faz 2 klinik çalışmalar bulunmaktadır ve bu konuyla ilgili araştırmalar devam etmektedir. Hastamızda tümörlerin yaygın şekilde büyümesi ve çevresindeki dokuları istila etmesi, tümörlerin rezeksiyonunu zorlaştırmıştır. Bu nedenle hasta nörofibromların büyüme hızını ve malign periferik sinir kılıfı tümörlerine dönüşümü değerlendirmek için yıllık MRG kontrolleri ile takip edildi. Bu olgu spinal MRG'sinde multipl PN'ler olması nedeni ile demonstratifti. Hastamızda olduğu gibi çok fazla sayıda PN'lerin varlığı nadir görülen bir durumdur.

Anahtar Kelimeler: Nörofibromatozis tip 1, pleksiform nörofibrom, spinal tümör

\section{Introduction}

Neurofibromatosis (NF) is a dominantly inherited disorder caused by mutations of the neurofibromatosis type 1 (NF1) or NF2 genes, which are respectively located at chromosome $17 \mathrm{q} 11.2$ and 22q12.2 (1,2). Loss of neurofibromin, which is an inactivator of protooncogen RAS, leads to an increase in tumorigenesis $(3,4)$. Therefore, patients are predisposed to having central nervous system tumors, especially gliomas, which are the most common neoplasms in NF1 (5). Plexiform neurofibromas (PNs) also occur in people with NF1. Clinical symptoms of neurofibromas, which may occur almost anywhere in the body, vary according to the localization of tumors. Impairment of vision, pain, muscle atrophy, paresthesia, and weakness were reported in patients with both NF1 and NF2 $(6,7)$.

\footnotetext{
Address for Correspondence/Yazışma Adresi: Tamer Bayram MD, Beykoz State Hospital, Clinic of Neurology, Istanbul, Turkey Phone: +90 5317941661 E-mail: tmrbyrm@gmail.com ORCID: orcid.org/0000-0003-0417-3542

Received/Geliş Tarihi: 11.04.2019 Accepted/Kabul Tarihi: 11.11 .2019

${ }^{\circ}$ Copyright 2020 by Turkish Neurological Society

Turkish Journal of Neurology published by Galenos Publishing House
} 
We present a 17-year-old boy with undiagnosed NF1-related multiple PNs. His cervical, thoracic, and especially lumbosacral spinal magnetic resonance imaging (MRI) was demonstrative and showed PNs in nearly all spinal segments. He was admitted to our department due to left limb paresthesia after being asymptomatic for many years.

\section{Case Report}

A 17-year-old male patient was admitted to our department because of subacute-onset progressive left limb paresthesia located at the L3-L4 dermatomes. On physical examination, widespread café-au-lait spots but no periaxillary/inguinal freckles or subcutaneous neurofibromas were found (Figure 1A, 1B).
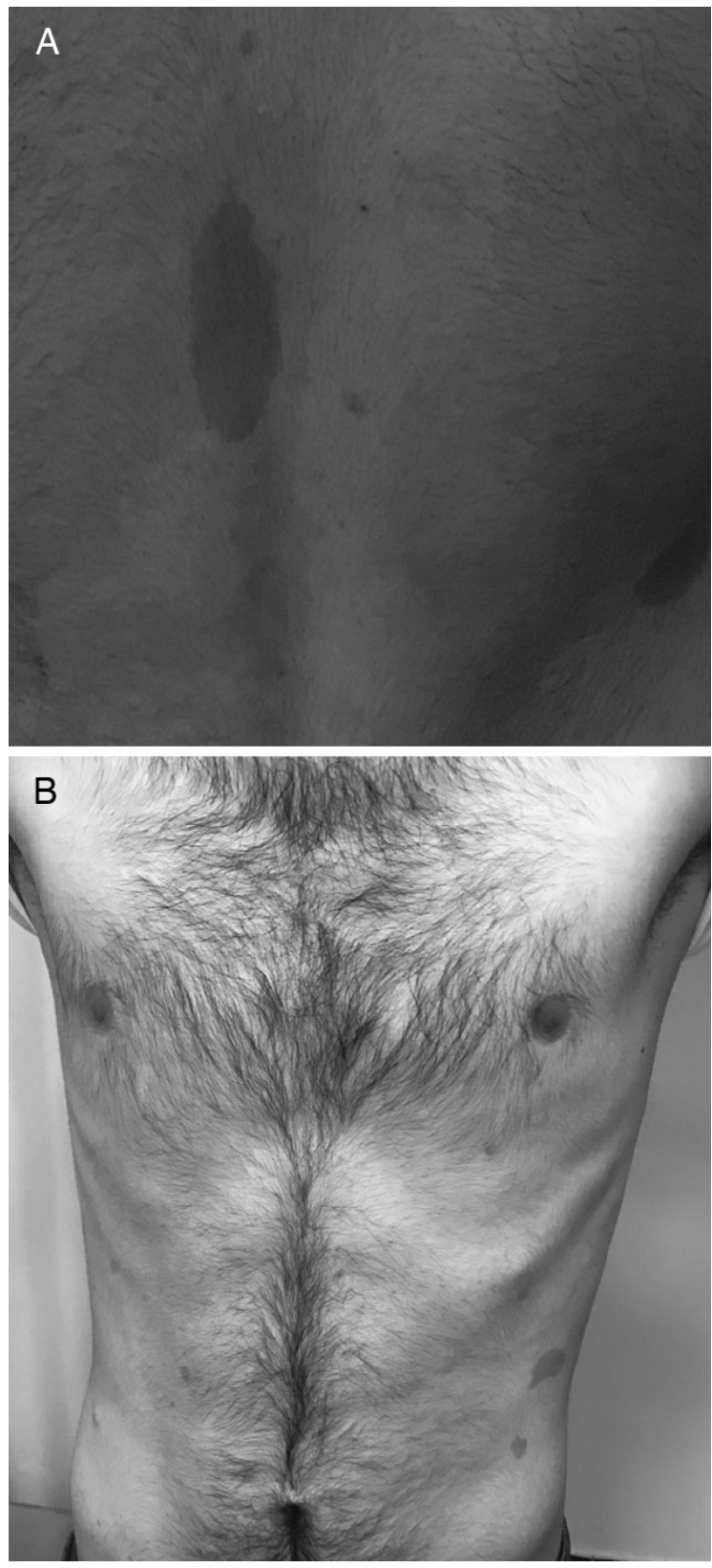

Figure 1. A, B) Café-au-lait spots on his body
A motor system examination revealed no muscle wasting. Deep tendon jerks were normal. There were no iris hamartomas or Lisch nodules. Routine hematology and biochemical investigation were normal. Brain MRI showed no abnormalities. Cervical (Figure 2), thoracic (Figure 3, 4), and lumbosacral (Figure 5A, 5B) MRI of the spine showed multiple lobulated nodular lesions, showing isohypointense signal in T1-weighted series and a mild hyperintense signal in T2-weighted series, in all neural foramina and in both paravertebral areas. Secondary to lesions, all neural foramina were enlarged. No significant contrast enhancement was observed in the lesions.

In thoracic MRI of spine, neurofibromas were observed along the costa from the level of the bilateral costovertebral connection. His lumbosacral MRI showed a large number of neurofibromas starting at the L2 segment and extending to the coccygeal region, and neurofibromas at the anterior of the bilateral iliac muscle fibers, and at the posterior of the psoas muscle fibers. A large number of neurofibromas were also detected in the presacral rectal region. These findings were consistent with PNs.

He was diagnosed as having NF1 based on clinical criteria established at the National Institute Health Consensus Conference (8). He refused to undergo genetic analysis and to have biopsy of the spinal nodular lesions. Among his family members, his father also had café-au-lait spots, but the others had no clinical evidence of NF1. MRIs of his family members could not be performed because they did not attend the outpatient clinic follow-ups.

Surgical resection of PNs in almost all spinal segments was not possible. Extensive growth of the tumors and invasion of surrounding tissues made resection of lesions difficult in the

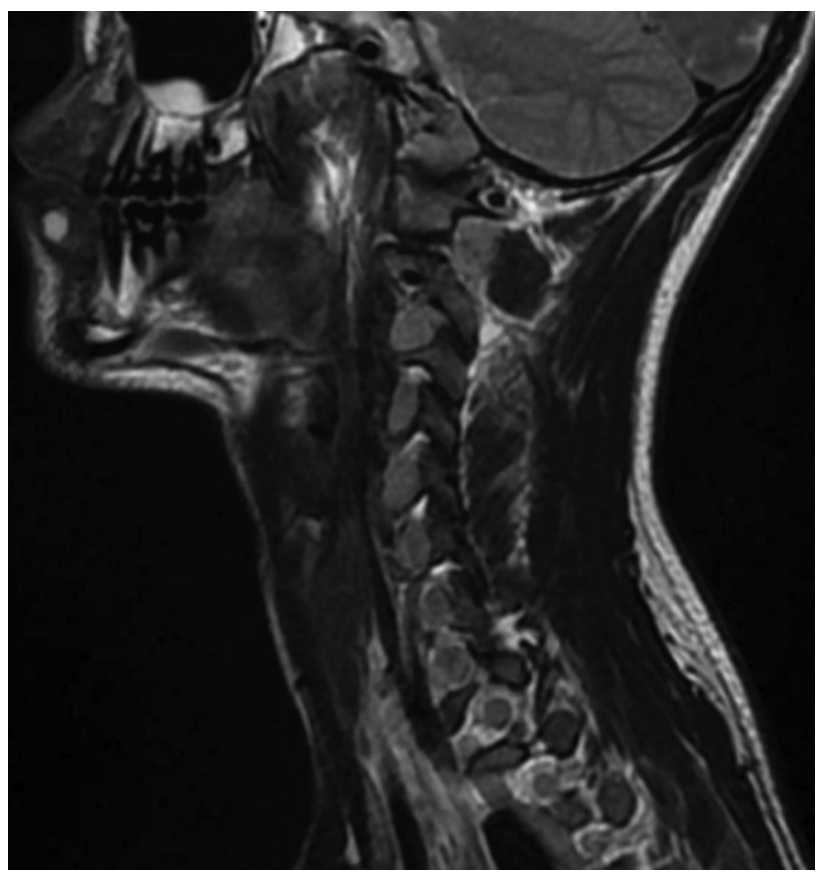

Figure 2. Cervical magnetic resonance imaging. Enlarged neural foramina secondary to neurofibromas and lesions showed mild hyperintense signal in T2-weighted series 


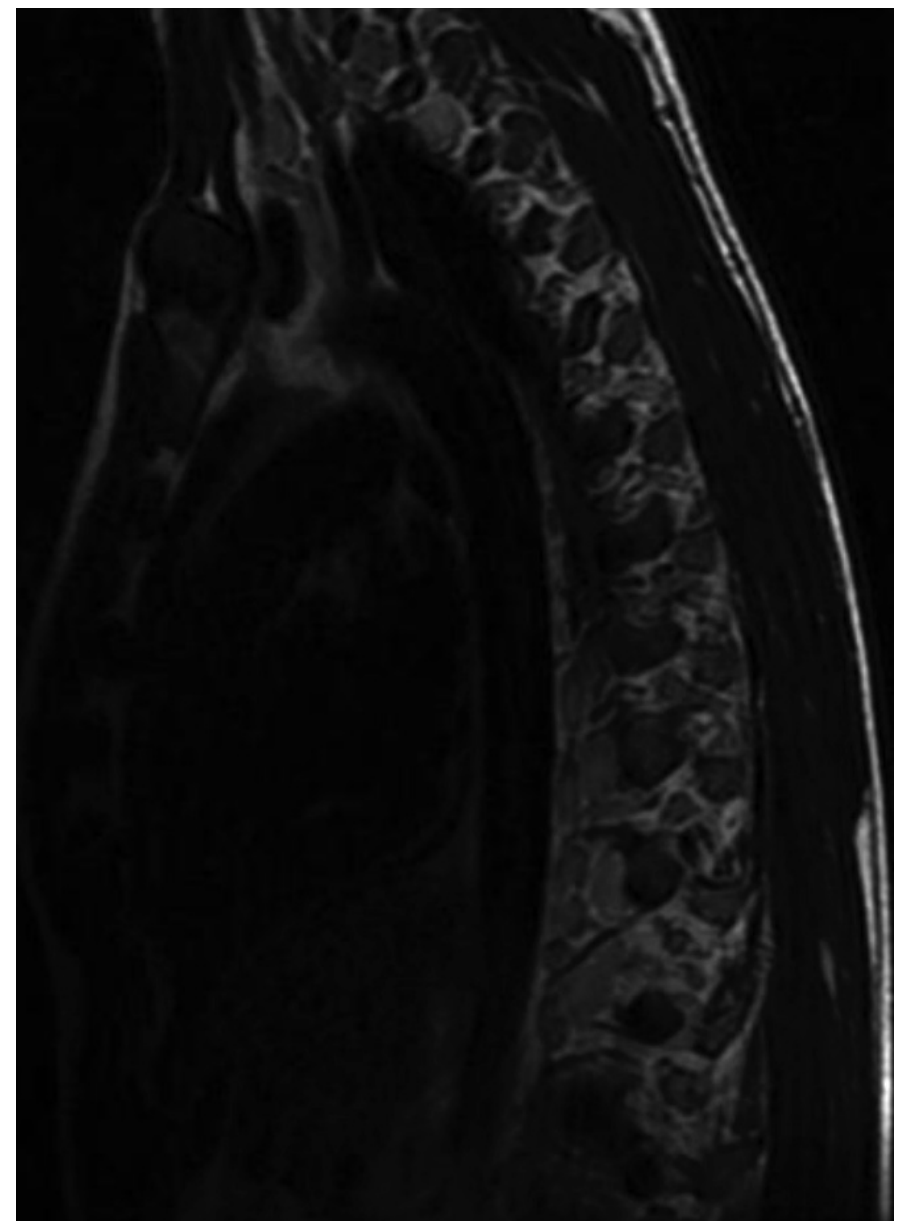

Figure 3. Thoracic magnetic resonance imaging. Enlarged neural foramina secondary to neurofibromas, multiple lobulated nodular lesions showed mild hyperintense signal in T2-weighted series

patient. He has been followed up with annual brain and spinal MRI to prevent long-term irreversible neurologic deficits.

\section{Discussion}

NF1 is an autosomal dominant neurocutaneous disease with a spontaneous mutation rate of $50 \%$. Its estimated birth incidence is 1:2000-3000 $(9,10)$. The defining features of NF1 are café-au-lait spots $(90 \%)$, intertriginous freckling, Lisch nodules, and dermal neurofibromas (90\%) and PNs (40\%) (two or more neurofibromas of any type or one PN), a first-degree relative with NF1. Optic pathway gliomas (7.5\%) and bony dysplasia (5\%) are less frequent. At least two criteria must be met for a diagnosis of NF1 (8). "Plexiform" does not imply tumor involving in a nerve plexus, the term means a network-like growth of neurofibroma involving multiple fascicles of a nerve and may include multiple branches of a large nerve (11). In the current case, the patient had widespread café-au-lait spots on physical examination and multiple PNs in MRI of spine. Even though he had no family medical history, a
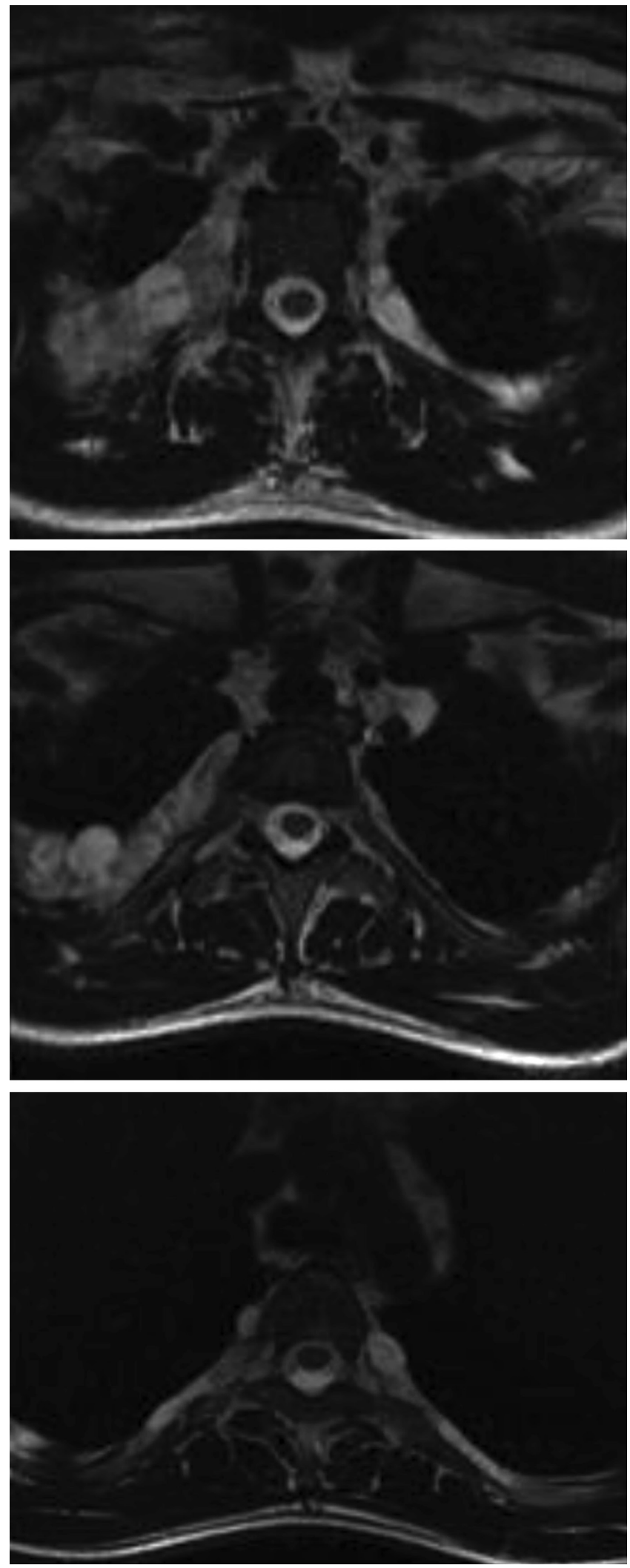

Figure 4. Thoracic magnetic resonance imaging of spine. Neurofibromas were bilaterally observed along the costa 

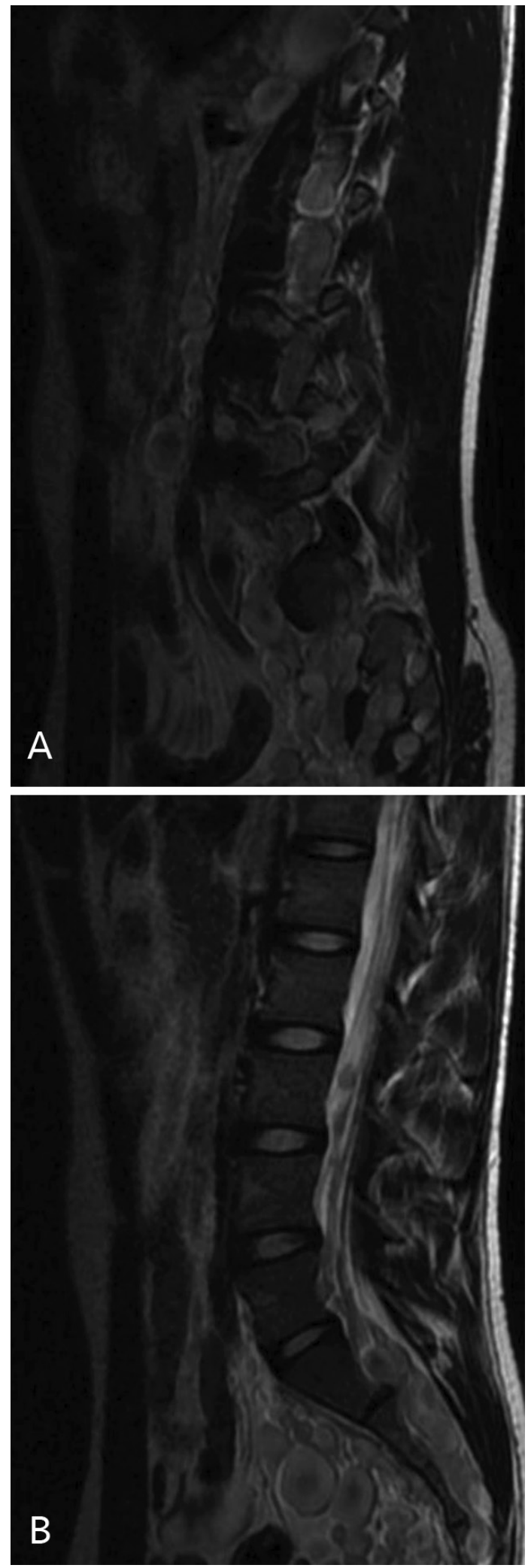

Figure 5. A, B) Lumbosacral magnetic resonance imaging. Plexiform neurofibromatosis are in the spinal canal and involve deep tissues, including the gastrointestinal tract or the urogenital area physical examination of his father showed multiple café-au-lait spots.

A lack of functional neurofibromin, a negative regulator of RAS activity, leads to tumorigenesis in patients with NF1 and NF2 gene mutations $(3,4,12)$. Patients with NF1 have an increased propensity for developing both benign and malignant tumors $(13,14)$. One of the most common benign tumors with NF1 are neurofibromas, which are always benign and have no potential for malignant transformation. In contrast, PNs can undergo malignant transformation and they are precursors of malignant peripheral nerve sheath tumors (MPNSTs) in particular (15). The risk of transformation to MPNST is approximately $10 \%(16,17)$. The incidence of PNs in patients with NF1 is $30 \%$ according to a population-based study (9). They may even be life-threatening.

PNs may be visible from the surface of the body, or may be internal with no evident superficial extension (18). An internal neurofibroma defines a neurofibroma that is not appreciated in a physical examination. The study of Sbidian et al. (19) showed that internal neurofibromas developed earlier in females than in males and their prevalence increased during adolescence. Age, xanthogranulomas, and presence of both subcutaneous and PNs were associated with internal neurofibromas.

Even though our patient had multiple NFs, there was no evidence in physical examination of his body and all these neurofibromas were asymptomatic until the age of 17 years. Studies of Tonsgard et al. (20) and Schorry et al. (21) have shown the frequency of PNs, respectively performed on 126 and 240 individuals with NF1. Most of the patients in these two studies were asymptomatic. Growth of PNs can occur at any time in life. It is suggested that PNs tend to grow in two distinct periods. First is early childhood, and the second is during times of hormonal changes such as during puberty or pregnancy (22). Changes in steroid hormone levels may affect the NF1 phenotype. Immunologic studies have provided support for this hypothesis by identifying the progesterone receptor in neurofibromas (23). In some cases, these may arise along the brachial or lumbar plexi, and extend from multiple spinal nerves (11). Thoracic root PNs may extend along intercostal nerves with or without superficial extension, as in our patient. PNs can also involve deep tissues, including the gastrointestinal tract or the urogenital area. Most of the NFs in the patient presented herein were in the presacral region.

Treatment of PN is surgical. Extensive growth of the tumor and invasion of surrounding tissues often makes total resection difficult. Postsurgery regrowth is also common. The choice of the optimal time for surgery is therefore challenging. Each tumor needs to be followed separately and one tumor cannot be used to evaluate the growth rate of all tumors. Patients who carry PNs that are not surgically resectable should undergo follow-up examinations with MRI to assess if tumor growth leads to functional deficits or transforms to MPNST $(24,25)$. Current guidelines for the management of patients with NF1 recommend imaging studies based on clinical signs or symptoms $(13,26)$. However, clinical indications for obtaining an MRI to evaluate PNs have not been established, and the optimal frequency of follow-up examinations has not been determined. Radiotherapy of PNs is contraindicated because of the risk of inducing MPNSTs in these genetically predisposed individuals (27). Positron emission tomography 
(PET) with F-18-fluorodeoxyglucose was reported to be sensitive in identifying malignancy arising in PNs in NF1 (28). Brenner et al. (29) were able to demonstrate that standardized uptake values in PET were a sensitive marker for predicting outcome in NF1 patients with MPNST. The combined application of MRI and PET gives no precise information on tumor grade (30).

There are phase 2 clinical trials of the agents tipifarnib, pirfenidone, sirolimus, PEGylated interferon alfa-2b, and imatinib, which target RAS signaling and other pathways. These clinical studies are investigating whether the drugs are effective in increasing the rate of progression-free survival or in reducing $\mathrm{PN}$ volumes. A recent study about the activity of selumetinib in NF1-related PNs suggested that (early-phase data) children with NF1 and inoperable PNs benefited from long-term dose-adjusted treatment with selumetinib without having excess toxic effects (31).

We presented a patient who was diagnosed as having NF1related multiple PNs. PNs are seen in patients with NF1, but the presence of as much multiple PNs as in our patient is rare. They have potential for malignant transformation and are frequently asymptomatic. Resection of multiple PNs and recurrence after resection are difficulties in treatment. Every patient with NF1 should receive long-term follow-up to prevent irreversible neurologic deficits and to detect tumoral lesions at earlier stages.

Ethics

Informed Consent: Informed consent was received from the subject involved in the study.

Peer-review: Externally peer-reviewed

\section{Authorship Contributions}

Concept: T.B., H.T., Design: D.B., T.B., Data Collection or Processing: D.B., Analysis or Interpretation: T.B., H.T., D.B., Literature Search: D.B., Writing: T.B., D.B.

Conflict of Interest: No conflict of interest was declared by the authors.

Financial Disclosure: The authors declared that this study received no financial support.

\section{References}

1. Jett K, Friedman JM. Clinical and genetic aspects of neurofibromatosis 1 . Genet Med 2010;12:1-11.

2. Yohay KH. The Genetic and Molecular Pathogenesis of NF1 and NF2. Semin Pediatr Neurol 2006;13:21-26.

3. Cichowski K, Jacks T. NF1 tumor suppressor gene function: narrowing the GAP. Cell 2001;104:593-604

4. Weiss B, Bollag G, Shannon K. Hyperactive Ras as a therapeutic target in neurofibromatosis type 1. Am J Med Genet 1999;89:14-22.

5. Rodriguez FJ, Perry A,Guttmann DH, et al. Gliomas in Neurofibromatosis Type 1: A clinicopathologic study of 100 patients. J Neuropathol Exp Neurol 2008;67:240-249.

6. Evans DG, Birch JM, Ramsden RT. Paediatric presentation of type 2 Neurofibromatosis. Arch Dis Child 1999;81:496-499.

7. Tucker T, Friedman JM, Friedrich RE, Wenzel R, Fünsterer C, Mautner VF. Longitudinal study of neurofibromatosis 1-associated plexiform neurofibromas. J Med Genet 2009;46:81-85.

8. No authors listed. Neurofibromatosis. Conference statement. National Institutes of Health Consensus Development Conference. Arch Neurol $1988 ; 45: 575-578$
9. Huson SM, Harper PS, Compston DA. Von Recklinghausen neurofibromatosis. a clinical and population study in south-east Wales. Brain 1988;111:13551381.

10. Lammert M, Friedman JM, Kluwe L, Mautner VF. Prevalence of neurofibromatosis 1 in German children at elementary school enrolment. Arch Dermatol 2005;141:71-74.

11. Korf BR. Plexiform Neurofibromas. Am J Med Genet 1999;89:31-37.

12. Ratner N, Miller SJ. A RASopathy gene commonly mutated in cancer: the neurofibromatosis type 1 tumour suppressor. Nat Rev Cancer 2015;15:290301.

13. Gutmann DH, Aylsworth A, Carey JC, et al. The diagnostic evaluation and multidisciplinary management of neurofibromatosis 1 and neurofibromatosis 2. JAMA 1997;278:51-57.

14. Hope DG, Mulvihill JJ. Malignancy in neurofibromatosis. Adv Neurol 1981;29:33-56.

15. Evans DG, Baser ME, McGaughran J, Sharif S, Howard E, Moran A. Malignant peripheral nerve sheath tumours in neurofibromatosis 1. J Med Genet 2002;39:311-314.

16. McGaughran JM, Harris DI, Donnai D, et al. A clinical study of type 1 neurofibromatosis in north west England. J Med Genet 1999;36:197-203.

17. Rasmussen SA, Yang Q, Friedman JM . Mortality in neurofibromatosis 1: an analysis using U.S. death certificates. Am J Hum Genet 2001;68:1110-1118.

18. Riccardi VM. Pathophysiology of neurofibromatosis. IV. Dermatologic insights into heterogeneity and pathogenesis. J Am Acad Dermatol 1980;3:157-166.

19. Sbidian E, Hadj-Rabia S, Riccardi VM, et al. Clinical characteristics predicting internal neurofibromas in 357 children with neurofibromatosis-1: results from a cross-sectional study. Orphanet J Rare Dis 2012;7:62.

20. Tonsgard JH, Kwak SM, Short MP, Dachman AH. CT imaging in adults with neurofibromatosis-1. Frequent asymptomatic plexiform lesions. Neurology 1988;50:1755-1760

21. Schorry EK, Crawford AH, Egelhoff JC, Lovell AM, Saal HM. Thoracic tumors in children with neurofibromatosis 1. Am J Med Genet 1997;74:533537.

22. Dugoff L, Sujansky E. Neurofibromatosis type 1 and pregnancy. Am J Med Genet 1996;66:7-10.

23. Overdiek A, Winner U, Mayatepek E, Rosenbaum T. Schwann cells from human neurofibromas show increased proliferation rates under the influence of progesterone. Pediatr Res 2008;64:40-43.

24. Mautner VF, Hartmann M, Kluwe L, Friedrich RE, Fünsterer C. MRI growth patterns of plexiform neurofibromas in patients with neurofibromatosis type 1. Neuroradiology 2006;48:160-165.

25. Mautner VF, Friedrich RE, von Deimling A, et al. Malignant peripheral nerve sheath tumours in neurofibromatosis type 1: MRI supports the diagnosis of malignant plexiform neurofibroma. Neuroradiology 2003;45:618-625.

26. Pinson S, Creange A, Barbarot $S$, et al. Neurofibromatosis 1:recommendations for management. Arch Pediatr 2002;9:49-60.

27. Ferner RE. Neurofibromatosis 1. Eur J Hum Genet 2007;15:131-138.

28. Ferner RE, Lucas JD, O'Doherty MJ, et al. Evaluation of (18) fluorodeoxyglucose positron emission tomography [(18)FDG PET] in the detection of malignant peripheral nerve sheath tumours arising from within plexiform neurofibromas in neurofibromatosis 1. J Neurol Neurosurg Psychiatry 2000;68:353-357.

29. Brenner W, Friedrich RE, Gawad KA, et al. Prognostic relevance of FDG PET in patients with neurofibromatosis type 1 and malignant peripheral nerve sheath tumours. Eur J Nucl Med Mol Imaging 2006;33:428-432.

30. Mautner VF, Brenner W, Fünsterer C, Hagel C, Gawad K, Friedrich RE. Clinical relevance of positron emission tomography and magnetic resonance imaging in the progression of internal plexiform neurofibroma in NF1. Anticancer Res 2007;27:1819-1822.

31. Dombi E, Baldwin A, Marcus LJ, et al. Activity of selumetinib in neurofibromatosis type 1-related plexiform neurofibromas. $\mathrm{N}$ Engl J Med 2016;375:2550-2560. 